\title{
IMPACT OF MICRO-FINANCE ON INCOME CHANGE OF WOMEN IN CHANDRAGIRI MUNICIPALITY
}

\author{
Gyanu Acharya \\ Lecturer, Department of Economics, Sanothimi Campus, Sanothimi, Bhaktapur, TU. \\ Corresponding author: gyanuacharya28@gmail.com
}

\begin{abstract}
This study aims to analyze the impact of micro-finance in income change of members of Women Co-operative Society (WCS). The study is based on both primary and secondary data. For this, 112 WCS' women of Thankot Branch were taken as population and among them 56 loan borrower members were randomly selected as sample of the study. The primary data were collected through a set of questionnaire. Secondary data were collected from the documents of WCS, Central Bureau of Statistics, Finance Ministry, the Government of Nepal. Different research reports, books and journals were also consulted as sources of secondary data. The collected data were analyzed by presenting them on tables and interpreted through percentage. The findings of the study show that the average monthly income of borrowers has increased by 31.14 percent after intervention of micro finance programme. Similarly, the average monthly income of the households has increased by 9.43 percent (21.71 percent difference between borrowers and households). All these show that WCS micro-finance program has contributed to the change in economic status of women by increasing their income.
\end{abstract}

Keywords: microfinance - economic change - women co-operative society collateral - compulsory deposit.

\section{BACKGROUND}

Most of the women are engaged in social and small scale economic activities along with the household works. Women play active roles as decision-makers and as participants in most works related to economic earning. Women also share responsibility of fetching water, collecting firewood, grass for domestic animals, carrying grains to the mills for grinding, planting and harvesting. They spend the largest amount of time mostly in unproductive 
activities from economic point of view. Owing to these realities, government policies to alleviate poverty and inequality for higher economic growth have become less effective. So, most of the women are the poorest of the poor in Nepal.

The economic dimension is central to achieve gender equality. Women are always empty handed and are more deprived groups. To minimize the gender-based economic inequality, different kinds of financial organizations like Grameen Bikas Bank (GBB), Women Co-operative Society Ltd (WCS), etc have launched their programme to provide micro credit without collateral to poor women. Yunus (1994) views that the moment we say microfinance everybody wants to help us. Following the same spirit, Adhikari and Shrestha (2013) concludes that microfinance enables the poor people to pull themselves out of poverty by providing them the collateral free loan and such loan is supportive to generate income. However, the practice of rustic credit in Nepal began in 1956 with the opening of credit cooperatives in Chitwan Valley to provide loans to the resettlers coming from different parts of the country (Shrestha 2009). The WCS Ltd., a cooperative financing organization promoted by 28 Women, was established in 1995 under the Cooperative Act 1992 (Co-operative Division) in order to provide micro credits and collateral free credits to poor women and bring them into development mainstream under microcredit program.

WCS's clients are landless women who form groups of five in order to receive loans for which no collateral is required. The idea of collateral, which cooperatives regard as sacred is to push the poor away from the WCS. The target of WCS is to mobilize internal urban/rural saving and external funds to provide credits and collateral free credits to poor, unskilled, uneducated women and bring them into development mainstream under micro-credit program. The group of women receive loan from WCS without collateral. In other words, WCS rejects collateral. WCS stipulates its loan strictly to be used for income generating activities. In this context, the present study attempts to identify the impact of WCS in the study area and suggest measures to improve the situation.

\section{STATEMENT OF THE PROBLEM}

Economic problem is more serious for development in Least Developed Countries (LDCs) like Nepal. Nearly 65.5 percent people are engaged in agricultural sector. Since the agricultural sector is the backbone 
of the development in the LDC's, its development can play vital role to uplift the nation's economy. For the lack of irrigation, fertilizers and agricultural credit, the productivity has been declining (CBS 2011). The Nepalese farmers have not enough agricultural land. Their farm depends on landlord land and due to the lack of permanent assets for collateral system, they have not got banking loan. In Nepal 16.67 percent of population live below poverty line (CBS 2019/20). Women are more affected as compared to men. However, the objective of five years' plans like 8 th, $9^{\text {th }}$ and $10^{\text {th }}$, three year interim plan and current $15^{\text {th }}$ plan was to eradicate poverty but has not succeeded to eradicate it.

The WCS concerns with poor women and women participation in economic activities since the main aim of the WCS is to participate women in economic activities. Most of the women are to be participated in WCS programme to make the women economically capable by handling the household level saving and other programmes: fortnightly meeting, loan proposal, repayment, compulsory deposit. According to this programme, women's life is to be uplifted. WCS has started to serve for poor women by providing them loan without collateral for economic change.

\section{OBJECTIVE OF THE STUDY}

The study aims to identify the impact of Women Co-operative Society to bring changes on the personal and family income of the members. Particularly, the study aims to identify the income growth of the WCS members in the study area.

\section{REVIEW OF RELATED LITERATURE}

Shehabuddin (1991) has emphasized that banking is possible without collateral so that its work is better for the poor people. He has further added that the social impact of the bank is seen in the gradually changing attitude among both the landless and the rural elite, they produce a future generation that values hard work.

In 1992 the government of Nepal setup five Grameen Bikash Bank as a replication of the Bangladesh Grameen Model of micro-finance delivery system. Government also created a situation to participate in the micro-finance by the private sector, like Nirdhan, Chhimek, Women Cooperative Ltd. and other private sectors developed MFIS which came into existence. Basically co-operatives are seen to depend on the small saving by the group members. 


\section{IMPACT OF MICRO-FINANCE ON INCOME CHANGE OF WOMEN IN ...}

Forwarding similar argument, Yunus (1994) says that poverty is not created by the poor, poverty is created by the existing world system which denies fair changes to the poor. Women have to depend upon totally their husbands after marriage because that right to the family property is only through husbands. So, women should be encouraged to participate in income generating activities in accordance with their existing social norms, customs and values.

According to UNEPA report (1997) on co-operative and women empowerment, micro finance is essential to increase the access of women to financial opportunities and resources: employment, land, technology along with other sources: education, health( the inseparable parts of human development) in order to promote women through social, financial, organizational and inclusive activities. The study of Chan and Ghani (2011) showed that micro finance has emerged as a popular mode of finance and a poverty reduction means, mainly in the developing countries, for the poor and small scale producers along with women and the disadvantaged communities.

Adhikari and Shrestha (2013) stated that microfinance is an effective tool for bringing positive impact on the economic status of the respondents along with their household members. It proved that it helps to generate extra income for their family and their own use. For this study, they selected 348 loanees and 193 non-loanees among the 541 members. They use 33 percent of the total population has been taken as a sample from 21 centers of the Manamaiju VDC of Kathmandu. Their study proved that microfinance programme has been very successful in the study area. The microfinance programme helped to uplift the economic status of the women who had taken loan from microfinance and became members of Women Support Cooperative Limited in Manamaiju VDC of Kathmandu district.

Shrestha (2014) conducted a research entitled "Agriculture Development of Community people through Co-operatives" to findout the impact of co-operatives on socio-economic sectors of stakeholder women. The study found that the impact of co-operatives was positive in the study area. After launching the co-operative programme, significant impact on community people was observed. The financial activities related to agriculture were found rapid in the presence of co-operatives. The women were found most effective agents for mobilization of resources. It was found that $88.57 \%$ members had good economic practices as a result their income increased by 
Rs. 1000/- per month. Similarly, the study of Dhakal ( 2018) analyzed the impact of micro-finance to poor and non-poor communities of Syangja district, Nepal. His study concluded that both poor and non-poor communities of the study area were equally benefited by the service of micro finance. The seminal study of Dhungana (2016) attempted to find out the role and contribution of micro finance particularly to the distribution of micro credit, creation of micro enterprises, generating income, capital expenditure. The study concluded that the role of micro finance in transforming economic status of people is positive and has the significant impact.

\section{METHODOLOGY OF THE STUDY}

The research was conducted to examine the economic impact of the WCS members 'after and before taking loan from the WCS micro finance programme. The study was analyzed with the help of some determinant variables: WCS members' income, household income, household saving, occupation of the members' and WCS loan amount. The research was carried out adopting mixed method including both quantitative and qualitative methods. This research aimed at identifying impact of the WCS in economic change of the members. To accomplish this study, both primary and secondary data were utilized. The members of Women Cooperative Society Ltd Thankot Branch were the primary sources of data. The primary data were collected through a set of questionnaire. Economic Survey (ES), Reports of National Planning Commission (NPC), Nepal in Figures published by Central Bureau of Statistics and various authentic books, articles, journals, were used as secondary sources of data.

The field survey was conducted in Chandi Bhairab Women Group, Bishnu Devi Women Group and Bijaypur Women Group under Thankot Branch of WCS's Chandragiri Municipality of Kathmandu district. Samples of 56 borrowers were randomly drawn from three group equally as the representative of 112 population. It covers the women who had borrowed loan from WCS Thankot Branch. So, the 112 (28 from Chandi Bhairab, 48 from Bishnudebi and 36 from Vijayapur Women Group in which 14 sample from Chand Bhairab, 24 from Bishnu Devi and 18 from Vijayapur Women group of WCS respectively) women borrowers of this branch were the population of the present study.

\section{RESULTS AND DISCUSSION}

The WCS has become one of the major programmes in Kathmandu for increasing the income of women. Thankot Branch is one of the branches, 
which aimed to increase the income of its members. It was established to bring income change of the borrowers and borrowers' household by the WCS micro-credit program. The progress of any WCS program depends upon quantity of investment and actual loan distribution. The researcher has tried to analyze the members' income and saving, family income and saving change by amount of loan and number of borrowers. The results and discussion derived from the data have been presented under various themes as follows.

\section{Loan amount of WCS}

Here, researcher has explained about the loan amount of WCS. It is based on members' saving. The WCS has collected members saving and distributed loan to them.The total loan amount of the members was Rs 1,880,881.82 and average loan amount was Rs 30,337.91 only. Here, WCS disbursed small amount of loan but impact was greater and helped members' income increment.

\section{Occupation condition}

Here, occupation denotes involvement of the respondents in different sectors like farming, lobour, office, and business before and after taking the loan from WCS Thankot Branch.

Table 1: Occupation of the borrowers before taking loan

\begin{tabular}{lll}
\hline Occupation type & Numbers & Percentage \\
\hline Farming & 20 & 35.71 \\
Labour & 17 & 30.36 \\
Office Workers & 5 & 8.92 \\
Business & 10 & 17.85 \\
No occupation & 4 & 7.14 \\
\hline Total & 56 & 100 \\
\hline
\end{tabular}

Source: Field survey, 2019

Table 1 shows that 35.71 percent sample borrowers were engaged in farming, 30.36 percent in laboring, 8.92 percent in office, 17.85 in business and 7.14 percent had not got any job before taking loan. The data show that most of the respondents have their own occupation except very few (i.e. about 7.14 percent). The office workers were engaged in private offices involving in lower status job. 
Table 2: Occupation of the borrowers after taking loan

\begin{tabular}{lll}
\hline Occupation type & Numbers & Percentage \\
\hline Farming & 21 & 37.50 \\
Labour & 15 & 26,79 \\
Office Workers & 0 & 0.00 \\
Business & 16 & 28.57 \\
No occupation & 4 & 7.14 \\
\hline Total & 56 & 100 \\
\hline
\end{tabular}

Source: Field survey, 2019

Table 2 shows that 37.5 percent sample respondents were engaged in farming, 26.79 percent in laboring, 28.57 in business and 7.14 percent had not got any job. The data show that engagement of farming and business slightly increase and none of the respondents was working in offices.

\section{Income increment}

In the study area, the finding shows a remarkable change in income of the WCS members and family income. The following table has showed household income of WCS members before borrowing loan.

Table 3: Household income before borrowing loan

\begin{tabular}{lll}
\hline Income (Rs) & Number & Percentage \\
\hline Below 5000 & 2 & 3.57 \\
$5000-20000$ & 24 & 42.86 \\
$20000-40000$ & 13 & 23.21 \\
$40000-60000$ & 9 & 16.07 \\
$60000-80000$ & 3 & 5.36 \\
$80000-100000$ & 1 & 1.79 \\
More than 100000 & 2 & 3.57 \\
Not stated & 2 & 3.57 \\
\hline Total & 56 & 100 \\
\hline
\end{tabular}

Source: Field survey, 2019

Table 3 shows that 3.57 percent respondents earned less than Rs $5000,42.86$ percent of respondents earned Rs 5000 to Rs 20000. Whereas 23.21 percent of respondents earned Rs 20000 to Rs 40000, 16.07 percent of respondents earned Rs 40000 to Rs 60000, 5.36 percent of total respondents earned Rs 60000 to Rs 80000 . Just 1.79 percent respondents earned Rs 80000 to Rs $100000,3.57$ percent earned more than Rs 100000 and 3.57 percent were not stated before borrowing loan. 
Table 4: Household income after borrowing loan

\begin{tabular}{lll}
\hline Income (Rs) & Number & Percentage \\
\hline Below 5000 & 2 & 3.57 \\
$5000-20000$ & 17 & 30.36 \\
$20000-40000$ & 15 & 26.78 \\
$40000-60000$ & 9 & 16.07 \\
$60000-80000$ & 3 & 5.38 \\
$80000-100000$ & 4 & 7.14 \\
More than 100000 & 1 & 1.78 \\
Not stated & 5 & 8.92 \\
\hline Total & 56 & 100 \\
\hline
\end{tabular}

Source: Field survey, 2019

Table 4 shows that 3.57 percent respondents earned less than Rs $5000,30.36$ percent of respondents earned Rs 5000 to Rs 20000 . Whereas 26.78 percent of respondents earned Rs 20000 to Rs 40000, 16.07 percentof respondents earned Rs 40000 to Rs 60000, 5.38 percent of total respondents earned Rs 60000 to Rs 80000 . Just 7.14 percent respondents earned Rs 80000 to Rs $100000,1.78$ percent earned more than Rs 100000 and 8.92 percent were not stated after borrowing loan.

Table 5: Personnel income before borrowing loan

\begin{tabular}{lll}
\hline Income (Rs) & Number & Percentage \\
\hline Below 5000 & 28 & 50.00 \\
$5000-10000$ & 7 & 12.50 \\
$10000-15000$ & 2 & 3.57 \\
$15000-20000$ & 2 & 3.57 \\
$20000-250000$ & 1 & 1.78 \\
$25000-30000$ & 2 & 3.57 \\
30000 to 40000 & 1 & 1.78 \\
40000 to 50000 & 1 & 1.78 \\
Not stated & 12 & 21.42 \\
\hline Total & 56 & 100 \\
\hline
\end{tabular}

Source: Field survey, 2019

Table 5 shows that 50.00 percent respondents earned less than Rs $5000,12.50$ percent of respondents earned Rs 5000 to Rs 10,000. Whereas 3.57 percent of respondents earned Rs 10,000 to Rs 15,000 and 3.57 percent of respondents earned Rs 15,000 to Rs 20,000. Similarly 1.78 percent of respondents earned 20,000 to 25000 and 3.57 percent respondents earned 25,000 to 30,000 income. Whereas 1.78 percent respondents earned 30,000 
to 40,000 income, 1.78 percent respondents earned 40,000 to 50,000 income and 21.42 percent of total respondents did not stated before borrowing loan.

Table 6: Personnel income after borrowing loan

\begin{tabular}{lll}
\hline Income (Rs) & Number & Percentage \\
\hline Below 5000 & 26 & 46.43 \\
$5000-10000$ & 18 & 32.14 \\
$10000-15000$ & 4 & 7.14 \\
$15000-20000$ & 1 & 1.78 \\
$20000-25000$ & 1 & 1.78 \\
$25000-30000$ & 2 & 3.57 \\
$30000-40000$ & 2 & 3.57 \\
$40000-100000$ & 2 & 3.57 \\
Not stated & 0 & 0.00 \\
\hline Total & 56 & 100 \\
\hline
\end{tabular}

Source: Field survey, 2019

Table 6 shows that 46.43 percent respondents earned less than Rs 5000, 32.14 percent of respondents earned Rs 5000 to Rs 10,000 and 7.14 percent of respondents earned Rs 10,000 to Rs 15,000. Whereas 1.78 percent of respondents earned Rs 15,000 to Rs 20,000, 1.78 percent of respondents earned Rs 20,000 to Rs 25,000. Similarly 3.57 percent of respondents earned Rs 25,000 to Rs 30,000, 3.57 earned Rs 30,000 to Rs 40,000 income and 3.57 percent of respondents earned Rs 40,000 to Rs 1,00000 income.

The average monthly income was Rs 8,608.52 before borrowing loan and Rs 11,288.90 after borrowing loan of the respondents. After borrowing loan income has increased to 31.14 percent income per month of the borrowers. It is proved that the objective of the research has significant. So, the WCS impact is positive of members' income increment.

The average monthly income of the household was Rs 42,889.19 before loan and Rs 46,934.18 after loan. After borrowing loan it has increased to 9.43 percent income per month of the household.So, the WCS impact is also positive in income increment of the members. It is proved that WCS's members families were strongly utilized the loan.

UNEPA report proved that on co-operative and women empowerment, micro finance is essential to increase the access of women to financial opportunities and resources. This research also proved that 
women's financial opportunities and resources are uplifted through WCS micro-finance programme.

The study of Shehabuddin emphasized that banking is possible without collateral so that its work is better for the poor people and social impact of the bank is seen in the gradually changing attitude among both the landless and the rural elite, they produce a future generation that values hard work. This research also proved that banking is possible without collateral and social impact of bank is also changed.

There are slight differences in income amount among the poor clients women's family through micro finance program of WCS. After the intervention of WCS, member's income has significantly increased. It is significant for the rural women. So, they have started new business i.e. poultry farm, goat farming, small shop. The WCS's argument is proved. It shows that the traditional occupation: labour, farming have been decreased. Before the intervention of WCS, women were engaged in household, agricultural sector and labour but after the intervention of WCS, their occupation has been changed.There is significant change in family income after the intervention of WCS.

The argument of Shrestha proved that the impact of co-operatives was positive in the study area. In this research, co-operative programme has significant impact on WCS women like income, saving and economic activities increment.

Basically co-operatives are seen to depend on the small saving by the group members. The argument of government of Nepal has proved that micro finance is possible to collect small saving and run the economic activities.

Yunus's argument also proved that poverty is not created by the poor, poverty is created by the existing world system which denies fair changes to the poor. So, women should be encouraged to participate in income generating activities in accordance with their existing social norms, customs and values. In this search, WCS members succeeded in poverty reduction and income increment. So, this study proves that loan amount of WCS has significantly diverted the poverty ridden rural women from traditional to non-traditional sector.

\section{CONCLUSION}

The economic and social status of women is very lower than men. Women are far behind from income generating activities or development 
programmes due to the lack of property and cash in hand. The majority of the women population should be included in national development programme and they should be decision makers.

The WCS Ltd., a co-operative financing organization promoted by 28 women, was established in 1995 and started to work through micro-credit loan programme only for poor women. From the field survey and calculation, the results show occupation, income have changed of the WCS women and have improved their economic status. There is significant impact of the borrowing loan in the study area after the intervention of WCS. It is proved that there is increase in income, property, utilization of saving, and occupation. As a result, WCS micro-credit programme has been highly successful to increase income and is able to bring women in development mainstream.

\section{REFERENCES}

Adhikari, D.B. \& Shrestha, J. (2013). Economic impact of microfinance in Nepal: A case study of Manamaiju Village Development Committee. Economic Journal of Development, 15\&16, 36-49.

CBS, (2016). Statistical pocket book. Kathmandu: CBS/N.

CBS, (2011). Population monograph of Nepal. Kathmandu: CBS/N.

CBS, (2011). Nepal living standard survey report. CBS/N.

CBS, (1996). Nepal living standard survey report. CBS/N.

Cooperative Division, Nepal(1992). Cooperative act 1992. Cooperative Division.

Chan, S.H. \&Ghani, M.A. (2011). The impact of micro loans in vulnerable remote areas: Evidence from Malaysia. Asia Pacific Business Review, 17(1): 45-66.

Dhakal, C.P.(2018). Micro-finance for poor and non-poor communities of Nepal. Tribhuvan University Journal, 32(2): 135-142.

Dhungana, B.R.(2016). Does micro-finance transform economic status of people? Evidence from western development region of Nepal. The Journal of University Grants Commission, 5(1): 35-48.

Ministry of Finance (2014). Economic survey. Kathmandu: Government of Nepal.

Ministry of Finance (2020). Economic survey. Kathmandu: Government of Nepal. 
National Women's Commission (2008).Gender based divided statistics. National Women's Commission.

National Planning Commission (1992). The eighth five year plan. Kathmandu: NPC/HMG

National Planning Commission (1997). The ninth five year plan. Kathmandu: $\mathrm{NPC} / \mathrm{HMG} / \mathrm{N}$.

National Planning Commission (2002). The tenth five year plan. Kathmandu: $\mathrm{NPC} / \mathrm{HMG} / \mathrm{N}$.

Shehabuddin, R. (1991). The impact of grameen bank in Bangladesh. USA: Havard Radeliffe Colleges.

Shrestha, P.L. (2014). Agriculture development of community people through co-operatives. An unpublished research report . Kathmandu: Research Centre, TU.

Shrestha, S.M.(2009). State of microfinance in Nepal. Kathmandu: Institute of microfinance.

UNEPA (1997). Co-operative and women empowerment. UNEPA

Women Cooperative Society( WCS). WCS act 1995. Kathmandu: WCS

Women Cooperative Society (2019). WCS achievement report. Kathmandu: WCS.

Yunus, M. (1994). The grameen banks as I see it. Mirpur, Dhaka: Grammeen Bank. 